\title{
Epstein-Barr virus (EBV)-associated miRNAs are important for the maintenance of EBV transformed B cells
}

\author{
Sarah Linnstaedt", Eva Gottwein, Micah Luftig, Bryan Cullen \\ From $12^{\text {th }}$ International Conference on Malignancies in AIDS and Other Acquired Immunodeficiencies \\ (ICMAOI) \\ Bethesda, MD, USA. 26-27 April, 2010
}

The human oncogenic gamma-herpesvirus, Epstein-Barr virus (EBV), infects approximately $95 \%$ of the adult human population and causes B-cell lymphomas in immune-compromised individuals, such as AIDS patients. EBV transforms primary human B cells into indefinitely proliferating lymphoblastoid cell lines (LCLs) in vitro, which represents an important model system for the transformation of B cells by EBV. EBV encodes 25 viral miRNA, but their role in virus replication and pathogenesis is unclear. Three of these miRNAs, miR-BHRF1-1, miR-BHRF1-2, and miR-BHRF1-3, are expressed during the latency III stage of EBV, the EBV gene expression pattern observed in AIDS-associated B cell lymphomas and LCLs. We have performed functional studies examining the roles of the three BHRF1 miRNAs during the transformation of primary B cells by EBV in vitro as well as in the maintenance of the transformed state in established LCL cultures. Our preliminary data suggest that at least one EBV miRNA is necessary for LCL outgrowth. EBV is also known to up-regulate a number of cellular microRNAs, including miR-155, and our preliminary data also suggest a role of miR-155 in the maintenance of LCLs. We are currently examining the mechanisms by which EBV and cellular microRNAs contribute to the growth and maintenance of LCLs. Together, our data point to a role for EBVencoded and EBV-induced miRNAs in EBV-induced cell transformation.

\section{Acknowledgements}

This article has been published as part of Infectious Agents and Cancer Volume 5 Supplement 1, 2010: Proceedings of the $12^{\text {th }}$ International Conference on Malignancies in AIDS and Other Acquired Immunodeficiencies (ICMAOI). The full contents of the supplement are available online at http://www.biomedcentral.com/1750-9378/5?issue=S1

Published: 11 October 2010

doi:10.1186/1750-9378-5-S1-A28

Cite this article as: Linnstaedt et al:: Epstein-Barr virus (EBV)-associated miRNAs are important for the maintenance of EBV transformed B cells. Infectious Agents and Cancer 2010 5(Suppl 1):A28.

\footnotetext{
* Correspondence: sarah.linnstaedt@gmail.com

Department of Molecular Genetics and Microbiology, Duke University,
} Durham, NC, USA

Submit your next manuscript to BioMed Central and take full advantage of:

- Convenient online submission

- Thorough peer review

- No space constraints or color figure charges

- Immediate publication on acceptance

- Inclusion in PubMed, CAS, Scopus and Google Scholar

- Research which is freely available for redistribution
() Biomed Central 